\title{
Water Use Efficiency in Saline Soils under Cotton Cultivation in the Tarim River Basin
}

\author{
Xiaoning Zhao ${ }^{1, *}$, Hussein Othmanli ${ }^{1}$, Theresa Schiller ${ }^{1}$, Chengyi Zhao ${ }^{2}$, Yu Sheng ${ }^{2}$, \\ Shamaila Zia ${ }^{3}$, Joachim Müller ${ }^{3}$ and Karl Stahr ${ }^{1}$
}

1 Institute of Soil Science and Land Evaluation, University of Hohenheim, Emil-Wolff-Str. 27, Stuttgart 70593, Germany; E-Mails: husseinothmanli@hotmail.com (H.O.); theresa.schiller@gmx.net (T.S.); karl.stahr@uni-hohenheim.de (K.S.)

2 Key Laboratory of Oasis Ecology and Desert Environment, Xinjiang Institute of Ecology and Geography, Chinese Academic of Science, Urumqi 830011, China; E-Mails: zcy@ms.xjb.ac.cn (C.Z.); shengyu@ms.xjb.ac.cn (Y.S.)

3 Institute of Agricultural Engineering, Hohenheim University, Stuttgart 70593, Germany; E-Mails: shamailazia@googlemail.com (S.Z.); joachim.mueller@uni-hohenheim.de (J.M.)

* Author to whom correspondence should be addressed; E-Mail: xiaoningzhao2012@gmail.com; Tel.: +49-711-459-239-80; Fax: +49-711-459-231-17.

Academic Editor: Markus Disse

Received: 9 January 2015 / Accepted: 12 June 2015 / Published: 19 June 2015

\begin{abstract}
The Tarim River Basin, the largest area of Chinese cotton production, is receiving increased attention because of serious environmental problems. At two experimental stations (Korla and Aksu), we studied the influence of salinity on cotton yield. Soil chemical and physical properties, soil water content, soil total suction and matric suction, cotton yield and water use efficiency under plastic mulched drip irrigation in different saline soils was measured during cotton growth season. The salinity $\left(\mathrm{mS} \cdot \mathrm{cm}^{-1}\right)$ were 17-25 (low) at Aksu and Korla, 29-50 (middle) at Aksu and 52-62 (high) at Aksu for ECe (Electrical conductivity measured in saturation-paste extract of soil) over the $100 \mathrm{~cm}$ soil profile. The soil water characteristic curves in different saline soils showed that the soil water content (15\%-23\%) at top $40 \mathrm{~cm}$ soil, lower total suction power (below $3500 \mathrm{kPa}$ ) and lower matric suction (below $30 \mathrm{kPa}$ ) in low saline soil at Korla had the highest water use efficiency $\left(10 \mathrm{~kg} \cdot \mathrm{ha}^{-1} \cdot \mathrm{mm}^{-1}\right)$ and highest irrigation water use efficiency $\left(12 \mathrm{~kg} \cdot \mathrm{ha}^{-1} \cdot \mathrm{mm}^{-1}\right)$ and highest yield $\left(6.64 \mathrm{t} \cdot \mathrm{ha}^{-1}\right)$. Higher water content below $30 \mathrm{~cm}$ in high saline soil increased the salinity risk and led to lower yield $\left(2.39 \mathrm{t} \cdot \mathrm{ha}^{-1}\right)$. Compared to low saline soils
\end{abstract}


at Aksu, the low saline soil at Korla saved $110 \mathrm{~mm}$ irrigation and $103 \mathrm{~mm}$ total water to reach $1 \mathrm{t} \cdot \mathrm{ha}^{-1}$ yield and increased water use efficiency by $5 \mathrm{~kg} \cdot \mathrm{ha}^{-1} \cdot \mathrm{mm}^{-1}$ and $7 \mathrm{~kg} \cdot \mathrm{ha}^{-1} \cdot \mathrm{mm}^{-1}$ for water use efficiency (WUE) and irrigation water use efficiency (IWUE) respectively.

Keywords: salinity; soil matric suction; soil osmotic suction; water use efficiency; Tarim River Basin

\section{Introduction}

The Tarim River Basin, the most important location for Chinese cotton production (corresponding to $3.7 \%$ of the world cotton production [1]), as a result of exploitation, gained attention because of serious environmental problems developing over the last 50 years: serious degradation of soil (more than $12 \times 10^{3} \mathrm{~km}^{2}$ of land desertification; approximately $112 T_{\mathrm{g}}$ of organic carbon was released into the atmosphere from 1970 to 2000 in the Tarim River basin [2]); increased water salinity (maximum salt concentration of the irrigation water increased between 1960 and 1998 from 1.3 to $7.8 \mathrm{~g} \cdot \mathrm{L}^{-1}$ [3]); water resource degradation (a 4-6 m drop in ground water levels from the 1960s to 1980s [2]; approximately $300 \mathrm{~km}$ of the Tarim River's lower reaches ran dry between the 1950s and 1970s, including the previous terminal lake Lop Nor [3]; arsenic concentration in the Tarim River was 4.2 times higher than international limits due to the use of pesticides [4]); and plant coverage reduction (Populus euphratica (Salicaceae family) forest acreage and biomass declined by 67\% and 50\% respectively from 1958 to 1978 and $3820 \mathrm{~km}^{2}$ of $P$. euphratica forest, and $200 \mathrm{~km}^{2}$ of shrub- and grassland were lost in the lower reaches between the 1950s and 1990s [2]). Accumulative salt and gypsum in the Tertiary sediments induced the big amount of saline and alkaline soil in Xinjiang $\left(71.61 \times 10^{4} \mathrm{ha}\right)$, which occupied $33.26 \%$ of all agricultural fields [5]. The salinity in surface water moved to the basin. Soil salinity increased with increasing irrigation water salinity levels also in plastic mulch drip irrigation [6].

"The main causes of Tarim River desiccation were the increase in the irrigated area of the headstream section in the upstream region, the rise in water consumption in the upper and middle reaches, and the construction of reservoirs in the mountain area" [7].

A cotton irrigation experiment demonstrated that drip irrigation under a cover of plastic mulch is an effective way to protect from unproductive soil evaporation and that a mild water deficit during the budding stage could significantly enhance cotton fiber yield and improve water use efficiency [8]. Plastic mulching significantly increased the harvesting of rainwater and significantly increased yield [9], An experiment in Shihezi University under varying soil water content, with $90 \%, 75 \%, 60 \%$ of field water capacity, showed that a higher soil water saturation is unfavorable for the growth of the cotton root system and the yield of cotton under mulched drip irrigation in Xinjiang [10]. Research on water use efficiency of cotton in the Tarim River Basin showed that the lower limits of optimum soil water indices for high yields, water-saving, and good quality of seeding, squaring, flowering, boll-opening stage of cotton are $65 \%, 65 \%, 72 \%, 63 \%$ of soil water capacity (at $100 \mathrm{~cm}$ depth), respectively [11]. In Xinjiang, the experimental fields with different soil matric potentials at $20 \mathrm{~cm}$ soil 
depth showed that percolation and the ratio of deep percolation with irrigation water all increased with increasing soil matric potential [12]. Irrigation type, irrigation amount, and irrigation time are the factors in agricultural production which most affect water use efficiency (WUE). Irrigation of cotton in Xinjiang indicated that the flowering and budding stages were the most suitable times to supply limited irrigation water, thus significantly improving WUE by 57\% [11]. At Aksu station (Xinjiang), a study of different limited irrigation $(80 \%, 70 \%, 60 \%, 50 \%$ and $40 \%$ of field capacity) impact on winter wheat growth was conducted and showed that periods of mild soil water depletion in the early vegetative growth period together with severe soil water depletion in the maturity stage of winter wheat is an optimal limited irrigation regime in this oasis [13]. The effects of soil moisture on cotton root length density and yield under drip irrigation with plastic mulch in the same station showed that the water stress caused root length density increase in lower soil layers [14].

Germination, emergence, and early seedling growth are considered to be more sensitive to salinity than later stages of cotton growth [15]. "The key to salinity control and to irrigation sustainability is leaching and it interacts closely with crop growth, irrigation methods and soil-physical properties. Whereas most soils in the saline wasteland of Xinjiang have low permeability, which is considered critical in reclamation, their infiltration capacity tends to decrease greatly due to corruption of soil structure as soils are saturated" [16]. To control soil secondary salinization, one should mainly establish irrigation-drainage systems and reduce irrigation amount [17]. The volume of irrigation water is a key factor in controlling salt accumulation; insufficient irrigation cannot guarantee enough leaching of soil salt because of a low infiltration volume [18]. The rate of irrigation also affects the salt accumulation: The lower the drip rate $\left(1.24 \mathrm{~L} \cdot \mathrm{h}^{-1}, 3 \mathrm{~h}\right.$ per time), the less the salt content along the soil depth; the higher the drip rate $\left(2.55 \mathrm{~L} \cdot \mathrm{h}^{-1}, 3 \mathrm{~h}\right.$ per time $)$, the greater the tendency of salt content to increase with horizontal distance [19].

Matric potential had a greater effect on organic matter decomposition than clay content [20]. The different soil matric potentials for the drip agricultural systems were studied at $20 \mathrm{~cm}$ soil depth in China and provided the best estimates for increasing crop yield, which included, for example, matric potentials higher than $-20 \mathrm{kPa}$ for cotton in Xinjiang province [12] and for oleic sunflower in Tianjing [21], $-35 \mathrm{kPa}$ for Radish field in the North China Plain [22], and $-10 \mathrm{kPa}$ for corn in Northwest China [23]. Soil water retention is influenced by soil texture [24,25] and structure [25-27], organic matter content [28,29], and bulk density [30]. The calcium carbonate content of soils in arid and semi-arid areas should also be taken into account, when available water values are estimated from textural considerations [31,32].

As research mentioned above indicates, those studies focused mainly on the effect of soil matric potential on water use, the osmotic potential on plant growth, and water use on the osmotic potential, respectively, but seldom mentioned their combination on water use under field plastic mulched drip irrigation in soils. The aims of this study were: (i) to quantify cotton agricultural hydrological features; (ii) to combine soil matric and osmotic suction on water use; (iii) to investigate water use efficiency in different saline soils under cotton cultivation as affected by plastic mulch and drip irrigation in the Tarim River Basin in China. 


\section{Materials and Methods}

\subsection{Site Description}

The experiment was conducted at the Aksu National Experimental Station of Oasis Farmland Ecosystems $\left(40^{\circ} 37^{\prime} \mathrm{N}, 80^{\circ} 45^{\prime} \mathrm{E}\right.$, altitude $\left.1028 \mathrm{~m}\right)$ and at Xinier Township, Korla City $\left(41^{\circ} 35^{\prime} \mathrm{N}\right.$, $86^{\circ} 09^{\prime} \mathrm{E}$, altitude $903 \mathrm{~m}$ ), Xinjiang, located in the Tarim River Basin (Table 1, Figure 1). It is a typical temperate arid climate, with mean minimum and maximum temperature during the study period (April-November) ranging between 16.6 and $34.8^{\circ} \mathrm{C}$. There are different degrees of soil salinity and alkalinity (Table 2).

Table 1. The basic information of two experimental stations in Tarim River Basin.

\begin{tabular}{ccccccccc}
\hline Site & Location & $\begin{array}{c}\text { Temp } \\
\left({ }^{\circ} \mathbf{C}\right)\end{array}$ & Prec (mm) & $\begin{array}{c}\text { Ele (m) } \\
\text { a.s.l. }\end{array}$ & $\begin{array}{c}\text { GWD } \\
(\mathbf{m})\end{array}$ & $\begin{array}{c}\text { Relative } \\
\text { Humidity }{ }^{\mathbf{a}} \mathbf{( \% )}\end{array}$ & $\begin{array}{c}\text { Wind Speed }^{\text {a }} \\
\left(\mathbf{k m} \cdot \mathbf{h}^{-1}\right)\end{array}$ & Soil Type \\
\hline \multirow{2}{*}{ Aksu } & $\begin{array}{c}40^{\circ} 37^{\prime} \mathrm{N} \\
80^{\circ} 45^{\prime} \mathrm{E}\end{array}$ & 11.0 & 71.6 & 1028 & 2.0 & 50.5 & 5.3 & Solonchak \\
\hline Korla & $\begin{array}{l}41^{\circ} 35^{\prime} \mathrm{N} \\
86^{\circ} 09^{\prime} \mathrm{E}\end{array}$ & 12.2 & 100.8 & 903 & 1.4 & 42.8 & 7.7 & Solonchak \\
\hline
\end{tabular}

Notes: Temp, annual average temperature from 1982 to 2012 [33]; Prec, annual total precipitation from 1982 to 2012 [33]; Ele, elevation; GWD, groundwater depth; a.s.1, above sea level; ${ }^{\text {a }}$ the annual average data from 1982 to 2012 [33].

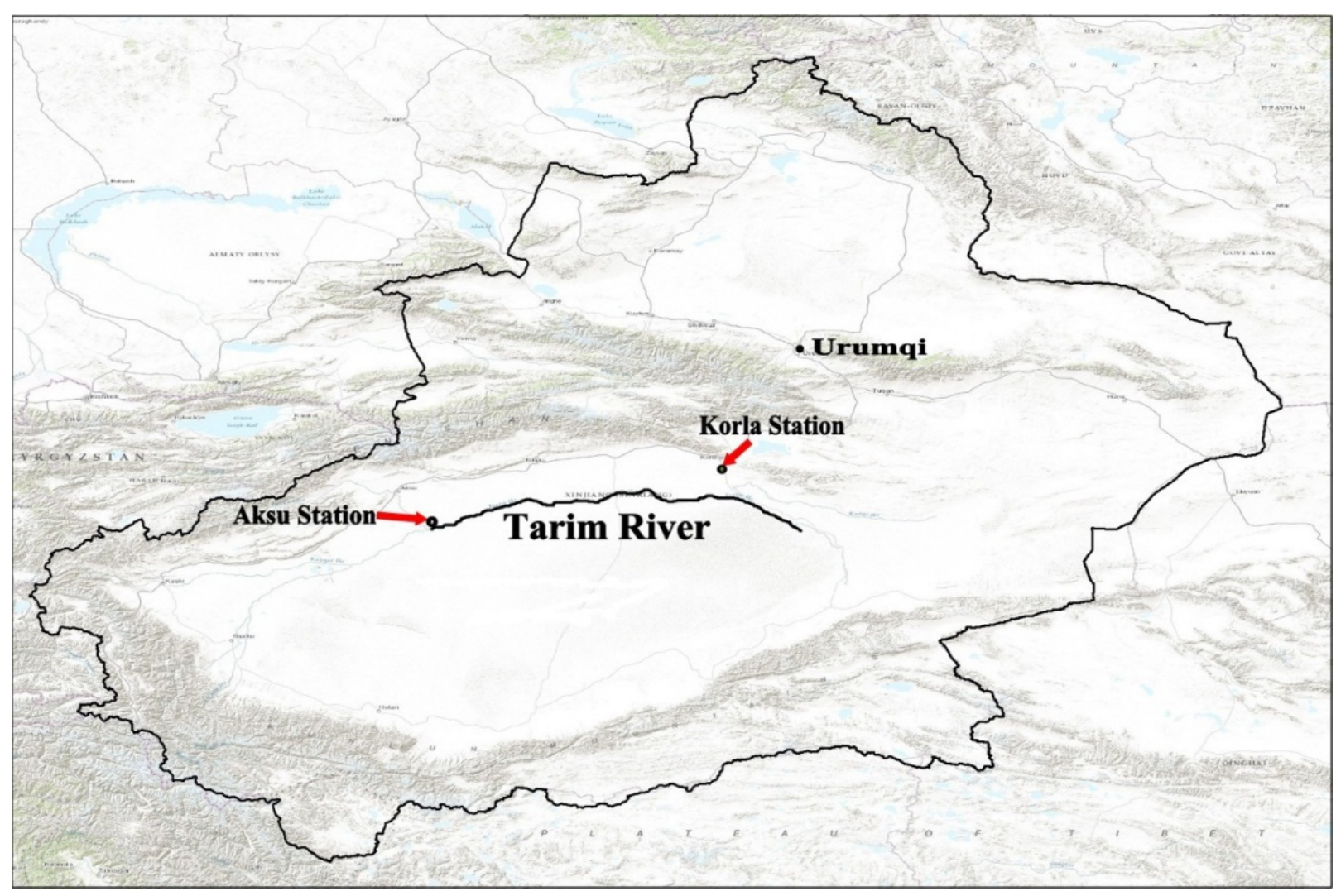

Figure 1. The location of the Aksu (left arrow) and Korla (right arrow) experimental stations in Tarim River Basin. 
Table 2. The soil chemical and physical properties of different saline soils in two experimental stations in Tarim River Basin.

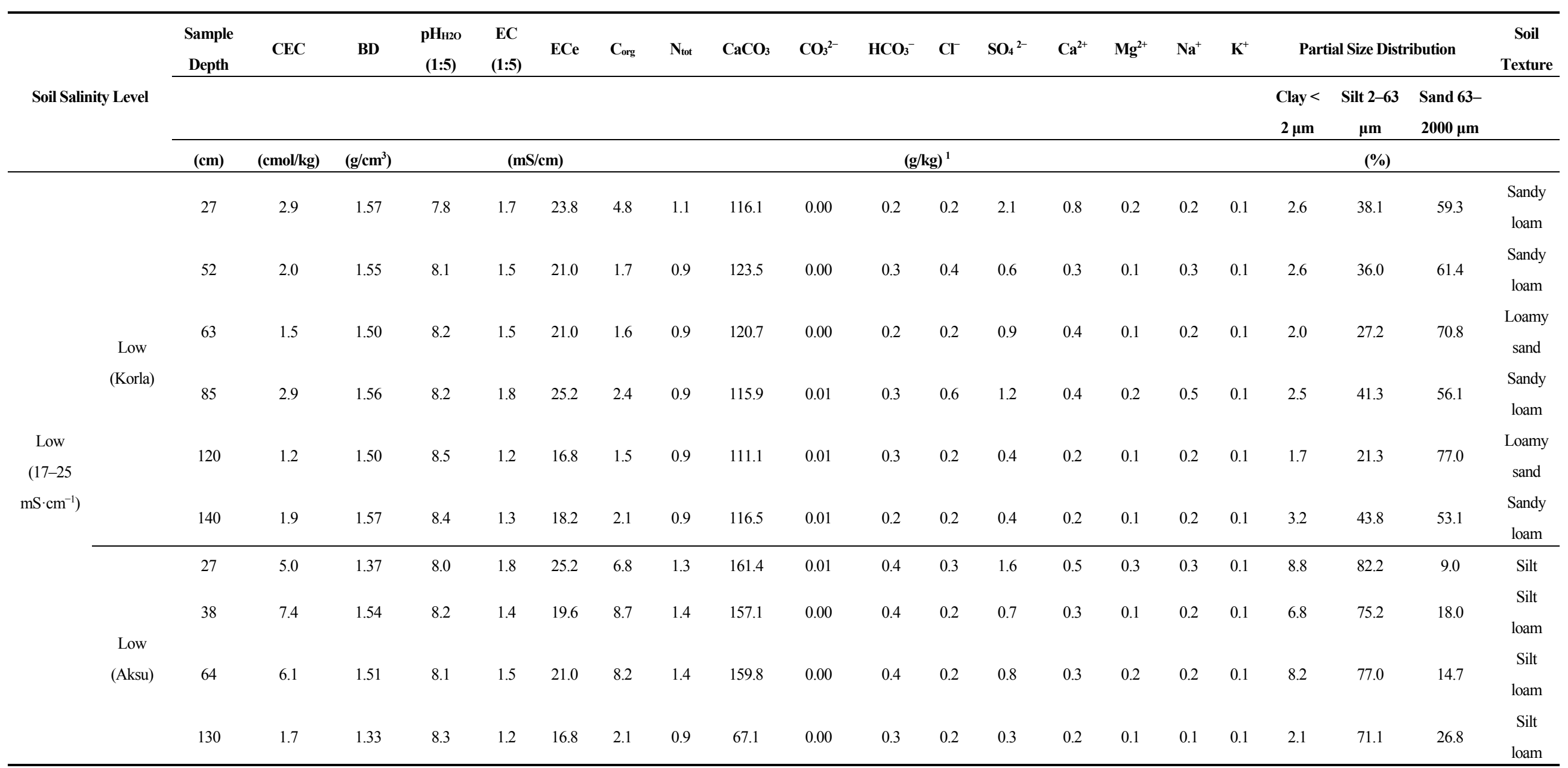


Table 2. Cont

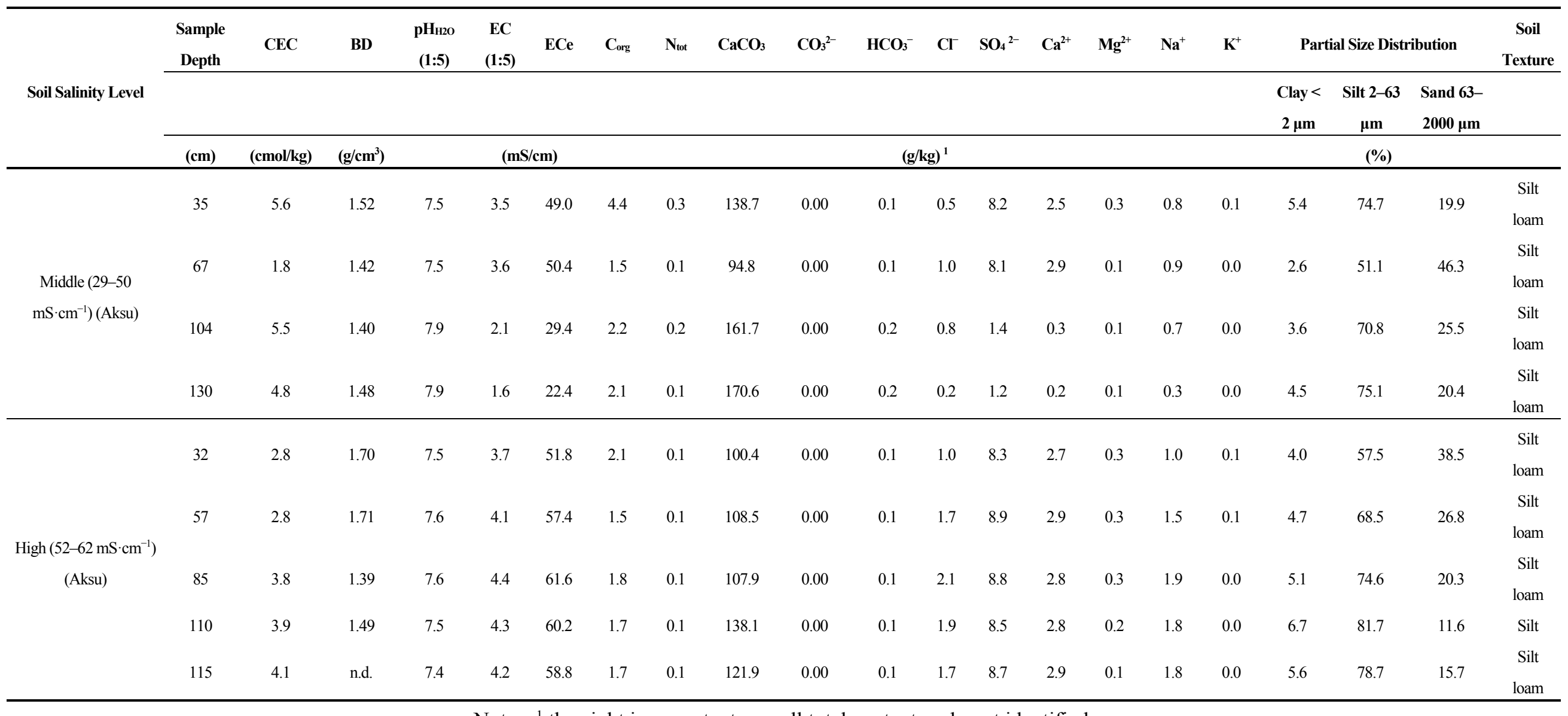

Notes: ${ }^{1}$ the eight ions content was all total content; n.d., not identified. 


\subsection{Experimental Design}

The cotton planting design was double rows with irrigation tubes (two tubes at Korla and one tube at Aksu) and one bare soil row (Figure 2). The salinity $\left(\mathrm{mS} \cdot \mathrm{cm}^{-1}\right)$ was $17-25$ (low) at Aksu and Korla, 29-50 (middle) at Aksu and 52-62 (high) at Aksu for ECe value over the $100 \mathrm{~cm}$ soil profile and two replicates per treatment, in which the soil matric potential at a depth of 25, 45, $65 \mathrm{~cm}$ was recorded. Every treatment had three replicates for TDR (Time Domain Reflectometer) and tensiometer.

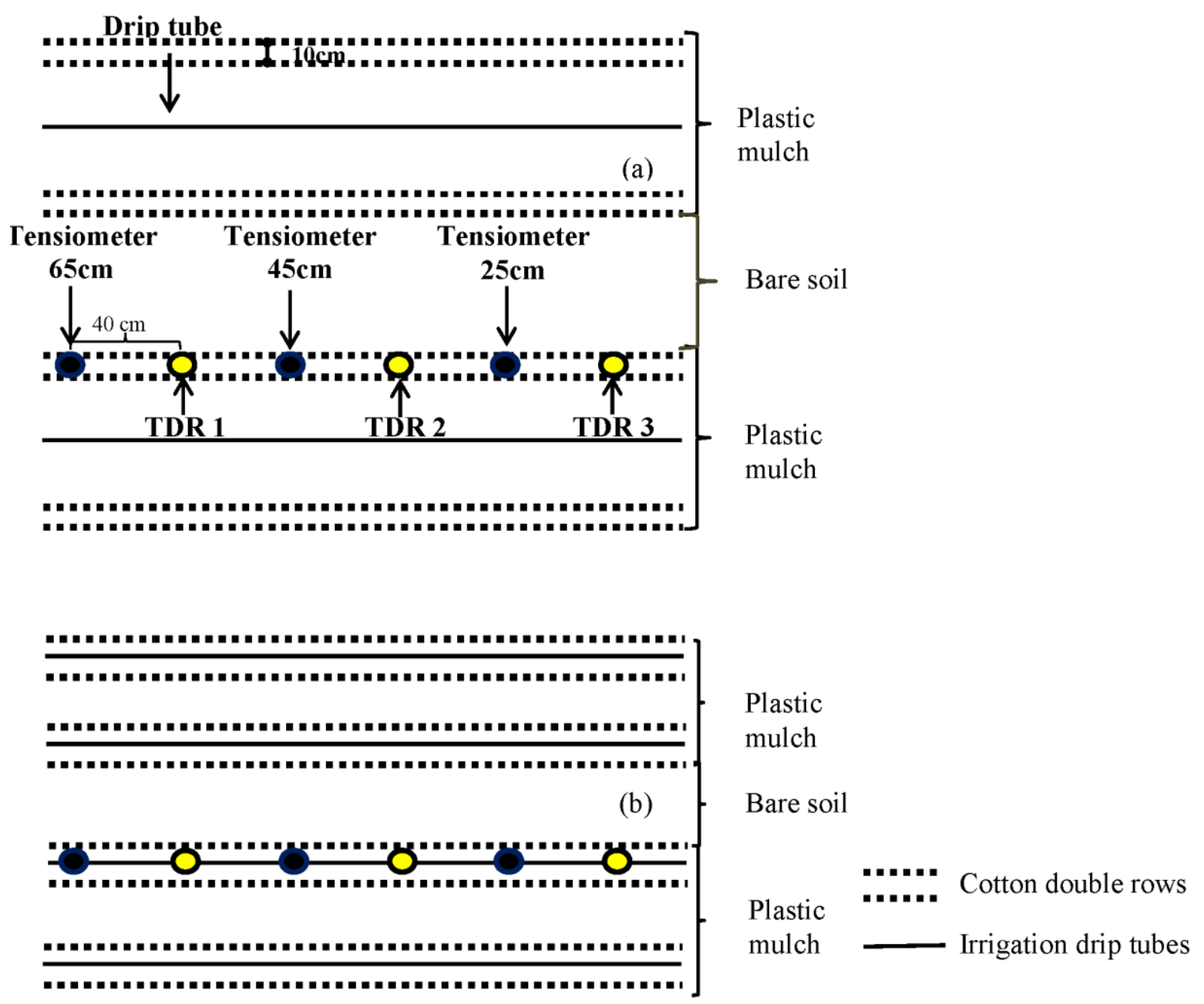

Figure 2. Field experimental design in different saline soils during cotton season from May to September 2012 in Tarim River Basin (a) at Aksu station and (b) at Korla station.

\subsection{Field Sampling and Laboratory Analysis}

Soil water content was measured by TDR-Time Domain Reflectometer (Time domain Reflectometry with Intelligent MicroElements-TRIME-PICO IPH) up to a depth of $85 \mathrm{~cm}$. Soil water potential was monitored in the morning hours using tensiometer P-80 (Mechanical ecoTech Tensiometer, ecoTech Umwelt-Meßsystem GmbH, Bonn, Germany) at 25, 45 and $65 \mathrm{~cm}$ depths. The TDRs and tension meters were set up between the cotton double rows and around $20 \mathrm{~cm}$ from the irrigation tube at Aksu and near the irrigation tube at Korla (Figure 2). The tensiometers were filled with distilled water and readings were taken every three days at the same time as TDR measurement in the fields. Soil samples 
were taken during harvesting season at Aksu and Korla. All soil samples were air-dried and sieved. Soil texture was determined using a granulometer. Bulk density was determined by the cylinder method. Organic carbon was measured by potassium bichromate titrimetric outside heating method. Total $\mathrm{N}$ was measured by perchloric acid-sulfate digestion using LWY84B an aluminum body digestion furnace and determination of nitrogen distiller. $\mathrm{CaCO}_{3}$ was measured by Gas Method. $\mathrm{CO}_{3}{ }^{2-}$ and $\mathrm{HCO}_{3}{ }^{-}$were measured by double indicator neutralization method. $\mathrm{Cl}^{-}$was measured by $\mathrm{AgNO}_{3}$ titration. $\mathrm{Ca}^{2+}, \mathrm{Mg}^{2+}$ and $\mathrm{SO}_{4}{ }^{2-}$ were measured by EDTA complexometry. $\mathrm{K}^{+}$and $\mathrm{Na}^{+}$were measured by flame photometry. All above methods used the analytical methods from Soil Agricultural Chemical Analysis [34]. At harvest, numbers of cotton bolls were recorded and cotton was collected from each replicate, oven-dried at $70{ }^{\circ} \mathrm{C}$ for $24 \mathrm{~h}$ and weighed to estimate yield. The cotton yield calculation was from the methods of the ministry of agriculture of the People's Republic of China [35].

Cotton seed yield $=$ plant density $\times$ average boll number per cotton plant $\times$ weight per boll $\times 0.85$

Average boll number per cotton plant $=$ boll with cotton + boll without cotton + $1 / 3 \times$ small boll (smaller than $2 \mathrm{~cm}$ )

\subsection{Calculations and Statistical Analysis}

\subsubsection{Soil Water Retention}

The soil water potential energy is the sum of matric potential $(\psi \mathrm{M})$, osmotic potential $(\psi 0)$, gas pressure potential $(\psi \mathrm{P})$ and gravitational potential $(\psi z)[36,37]$.

$$
\psi_{\mathrm{T}}=\psi_{\mathrm{M}}+\psi_{\mathrm{O}}+\psi_{\mathrm{P}}+\psi_{\mathrm{Z}}
$$

$\psi_{\text {T: }}$ the total soil water potential.

In unsaturated soils, gas pressure potential is zero and gravitational potential is a relative value from an arbitrary reference level [37], so the equation is changed to Equation (4). We selected $25 \mathrm{~cm}$ below the soil surface as the reference level.

$$
\psi_{\mathrm{T}}=\psi_{\mathrm{M}}+\psi_{\mathrm{O}}+\psi_{\mathrm{Z}}
$$

"The osmotic potential results from the reduction in energy of the water (relative to that of pure, free water) resulting from mixing the water with a solute" [36]. Osmotic potential is due to the solute in soil water. The EC $1: 5$ was converted to ECe using the following equation [38].

$$
\mathrm{ECe}=(14.0-0.13 \times \text { clay } \%) \times \mathrm{EC}_{1: 5}
$$

The osmotic potential of soil water was determined using the following equation from the United States Salinity Laboratory [39].

$$
\psi \mathrm{O}=-0.036 \mathrm{EC} \text { meas } \theta_{\text {ref }} / \theta_{\text {act }}
$$

\%०: the osmotic potential $(\mathrm{MPa})$ at the actual moisture content; $\mathrm{EC}_{\text {meas: }}$ the measured electrical conductivity $\left(\mathrm{mS} \cdot \mathrm{cm}^{-1}\right)$ of the extract at the reference water content (1:5 soil/water); $\theta_{\text {ref: }}$ the reference water content $\left(\mathrm{g} \cdot \mathrm{g}^{-1}\right)$ at 1:5 soil/water; $\theta_{\text {act: }}$ the actual moisture content $\left(\mathrm{g} \cdot \mathrm{g}^{-1}\right)$. 


\subsubsection{Water Use Efficiency (WUE)}

The total cotton evapotranspiration (ETc) for different salinity (low at Korla, low, middle, high at Aksu) soils during cotton season from May to September 2012 in Tarim Basin was estimated using the water balance method as follows [12]:

$$
\mathrm{ETc}=I+P \pm \Delta S-R-D
$$

$I$ : irrigation amount; $P$ : precipitation; $\Delta S$ : change of soil water storage in $1 \mathrm{~m} ; R$ : surface runoff; $D$ : downward flux below the crop root zone.

The soil water content of the soil profile (down to $80 \mathrm{~cm}$ ) was measured by TDR during the cotton growing season in 2012 , which was used for $\Delta S$ estimation, because $85 \%$ of the cotton roots were distributed in the top $30 \mathrm{~cm}$ of soil under mulched drip irrigation [10]. Surface runoff $(R)$ was ignored because precipitation was not high and no gradient of movement was observed.

Then water use efficiency (WUE $\mathrm{t} \cdot \mathrm{ha}^{-1} \cdot \mathrm{mm}^{-1}$ ) and irrigation water use efficiency (IWUE $\left.\mathrm{t} \cdot \mathrm{ha}^{-1} \cdot \mathrm{mm}^{-1}\right)$ is defined by the following equations [12]:

$$
\begin{gathered}
\mathrm{WUE}=Y / \mathrm{ET}_{\mathrm{C}} \\
\mathrm{IWUE}=Y / I
\end{gathered}
$$

$Y$ is the seed cotton yield $\left(\mathrm{t} \mathrm{ha}^{-1}\right)$ and $I$ is the irrigation water applied (mm).

\subsubsection{Statistical Analysis}

Using SAS 9.1 software, one way ANOVA was used to evaluate the effects of treatments on water use efficiency. Student $t$ test $(p \leq 0.05)$ was used to compare and rank the treatment means. To count the average data, two replicates were randomly located in the field except for the edge of the field. Statistic 10.0 software was used for soil water model lineal parameter estimation with Quasi-Newton estimation method.

\section{Results}

\subsection{Soil Chemical and Physical Properties of Different Saline Soils}

The ECe value increased from 17 to $62 \mathrm{mS} \cdot \mathrm{cm}^{-1}$ throughout the soil profiles. Sodium increased with the increase of EC. Using the linear relationship between EC $\left(\mathrm{dS} \cdot \mathrm{m}^{-1}\right)$ and soil salt content $\left(\mathrm{g} \cdot \mathrm{kg}^{-1}\right)$ with equation $y=4.6 x$ (EC was the variable) in Aksu water balance station [40]. The cotton critical soil salt content, cotton threshold soil salt content, the soil salt content at the fastest rate of cotton relative yield reduction, and the soil salt content at the $50 \%$ cotton relative yield reduction were $0.302 \%\left(0.66 \mathrm{mS} \cdot \mathrm{cm}^{-1}\right), 1.119 \%\left(2.43 \mathrm{mS} \cdot \mathrm{cm}^{-1}\right), 0.558 \%\left(1.21 \mathrm{mS} \cdot \mathrm{cm}^{-1}\right), 0.581 \%\left(1.26 \mathrm{mS} \cdot \mathrm{cm}^{-1}\right)$ at 0-20 cm soil layer at Aksu river irrigation district respectively [41]. In the experiment, low salinity at Korla and Aksu was under the cotton soil salt content threshold; however the middle and high salinity level at Aksu were higher than cotton soil salt content threshold. Here the ECe data were much higher than the international accepted limit of $15 \mathrm{dS} \cdot \mathrm{m}^{-1}$ for high salinity [42], but the general high level of salt in Xinjiang was also documented in the locally used limits. There were higher yield data (3.0 to $\left.5.9 \mathrm{t} \cdot \mathrm{ha}^{-1}\right)$ with top soil EC $\left(3-11 \mathrm{dS} \cdot \mathrm{m}^{-1}\right)$ in the south Xinjiang documented [43]. The $\mathrm{Na}^{+}$content 
increased as the soil salinity level increases from 0.1 to $1.8 \mathrm{~g} \cdot \mathrm{kg}^{-1} \cdot \mathrm{Na}^{+}$content was also used to define the different soil salinity levels because the ions that lead to salinization increase in importance in the following order: $\mathrm{Mg}^{2+}<<\mathrm{Ca}^{2+}<\mathrm{SO}_{4}{ }^{2-}<\mathrm{Cl}^{-}=\mathrm{Na}^{+}$[44]. Soil texture in the top $30 \mathrm{~cm}$ soils were: sandy loam in low saline soil at Korla, silt in the low saline soil at Aksu, and silt loam in the middle and high saline soils at Aksu (Table 2).

The high saline $30 \mathrm{~cm}$ topsoil at Aksu had the lowest CEC $\left(2.8 \mathrm{cmol} \cdot \mathrm{kg}^{-1}\right)$, highest bulk density $\left(1.70 \mathrm{~g} \cdot \mathrm{cm}^{-3}\right)$, lowest organic carbon content $\left(2.1 \mathrm{~g} \cdot \mathrm{kg}^{-1}\right)$, highest $\mathrm{SO}_{4}{ }^{2-}$ content $\left(8.3 \mathrm{~g} \cdot \mathrm{kg}^{-1}\right)$ and the highest calcium content $\left(2.7 \mathrm{~g} \cdot \mathrm{kg}^{-1}\right)$. The low saline $30 \mathrm{~cm}$ topsoil at Aksu had the lowest bulk density $\left(1.37 \mathrm{~g} \cdot \mathrm{cm}^{-3}\right)$, the highest organic carbon content $\left(6.8 \mathrm{~g} \cdot \mathrm{kg}^{-1}\right)$, the highest total nitrogen content $\left(1.3 \mathrm{~g} \cdot \mathrm{kg}^{-1}\right)$, lowest $\mathrm{SO}_{4}{ }^{2-}$ content $\left(1.6 \mathrm{~g} \cdot \mathrm{kg}^{-1}\right)$, the lowest calcium content $\left(0.5 \mathrm{~g} \cdot \mathrm{kg}^{-1}\right)$ (Table 2). Within the data, bulk density of $1.7 \mathrm{~g} \cdot \mathrm{cm}^{-3}$ is already high, but $1.37 \mathrm{~g} \cdot \mathrm{cm}^{-3}$ is medium.

\subsection{Soil Water Retention in Different Saline Soils at Different Soil Depths}

The water content was higher in low saline soil $(20 \%-29 \%)$ than in middle saline soil $(18 \%-24 \%)$ at Aksu and in low saline soil (15\%-23\%) at Korla in 0 to $40 \mathrm{~cm}$ depth (Figure 3), where the most cotton roots were distributed. Soil water content was highest in August in all soils. Soil water content changed strongly in the high saline soil (Figure 3d). The highest soil water content (57\%) was observed in July at $70 \mathrm{~cm}$ depth soil of the high saline soil, while the lowest soil water content (15\%) was observed in July at $30 \mathrm{~cm}$ depth soil of the low saline soil at Korla.

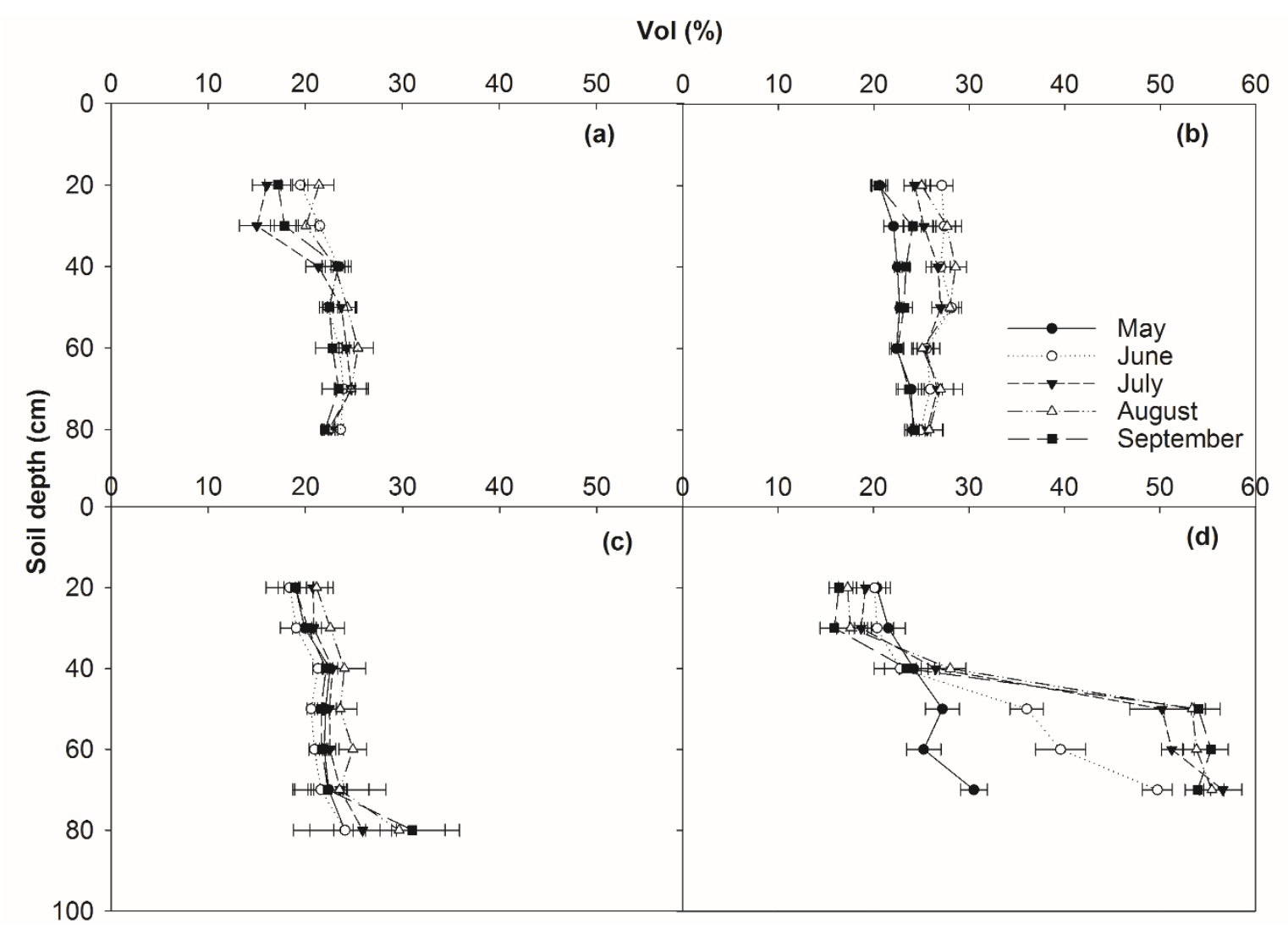

Figure 3. The soil water content in different soil depths $(0-80 \mathrm{~cm})$ during cotton season from May to September 2012 in Tarim River Basin (a) in low saline soil at Korla; (b) in low saline soil at Aksu; (c) in middle saline soil at Aksu; and (d) in high saline soil at Aksu. 
The soil in $25 \mathrm{~cm}$ depth had the highest matric suction in all saline soils from May to October in 2012, which was followed by $45 \mathrm{~cm}$ depth and $65 \mathrm{~cm}$ depth because of surface evapotranspiration, new soil organic carbon input from root growth and increasing moisture in deeper soil profile (Figure 4). The soil matric suction fluctuated from 2 to $72 \mathrm{kPa}$ in low saline soil and 12-52 $\mathrm{kPa}$ in middle saline soil at Aksu from May to October in 2012 compared to that in high saline soil $(2-12 \mathrm{kPa})$ and low saline soil at Korla (5-31 kPa) (Figure 4). In the $25 \mathrm{~cm}$ soil depth, the matric suction was highest $(72 \mathrm{kPa})$ and lowest $(2 \mathrm{kPa})$ in low saline soil at Aksu compared to the other soils (Figure 4). The matric suction power of the high saline soil remained constant in all three soil depths because of the high soil water saturation problems (Figure 4).

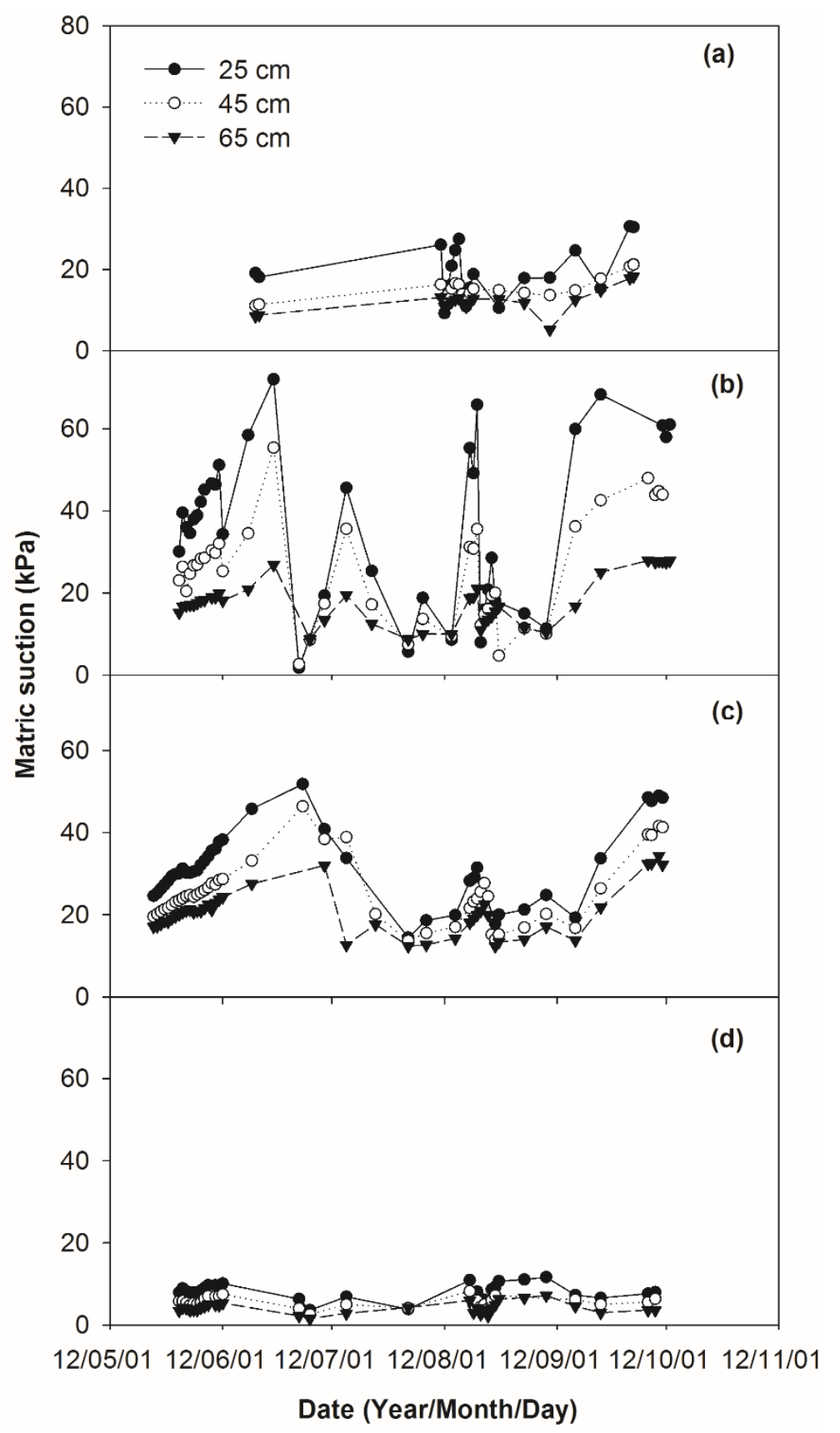

Figure 4. The soil matric suction in different soil depths $(25 \mathrm{~cm}, 45,65 \mathrm{~cm})$ during cotton season from May to October 2012 in Tarim River Basin (a) in low saline soil at Korla; (b) in low saline soil at Aksu; (c) in middle saline soil at Aksu; and (d) in high saline soil at Aksu. 
The soil salinity level mainly effects osmotic suction and the total suction. The highest total suction power was $5400 \mathrm{kPa}$ at $25 \mathrm{~cm}$ soil depth in higher saline soil and the lowest (1100 kPa) was in the low saline soil at $45 \mathrm{~cm}$ soil depth at Aksu (Figure 5). At all soil depths, the suction power of the high and middle saline soils was higher than that in the low saline soils (at Aksu and Korla), the order was: the total suction power of the high saline soil $(2200-5400 \mathrm{kPa})>$ middle saline soil $(3800-5200 \mathrm{kPa})>$ low saline soil at Aksu (1100-2200 kPa) and Korla (1600-3500 kPa). From the water content and the matric suction, all soil would not have strong water stress at any time. The irrigation obviously was insufficient to bring the total suction above the wilting point $(15,000 \mathrm{kPa})$, therefore the cotton could withdraw water at any time, but the medium and high saline soil already had these problems.

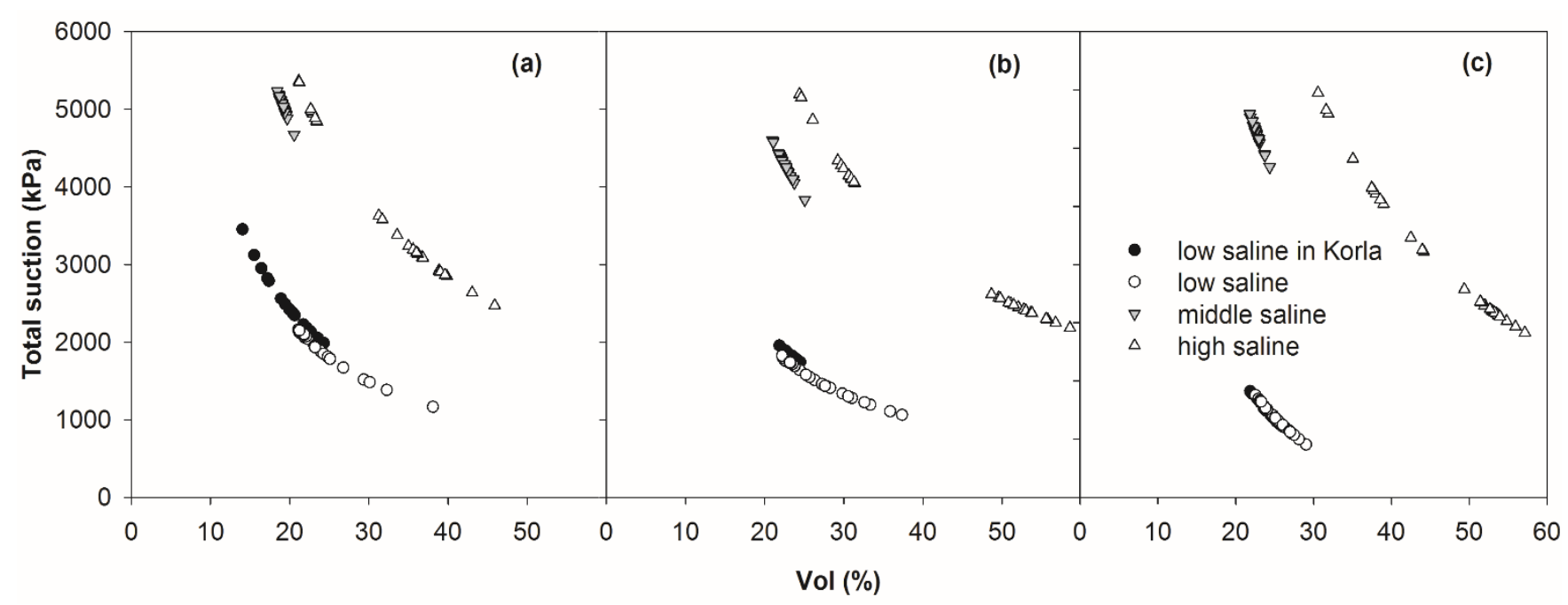

Figure 5. The soil water characteristic curves (matric and osmotic suction) in different saline (low at Korla, low, middle and high at Aksu) soils during cotton season from May to September 2012 in Tarim Basin (a) in $25 \mathrm{~cm}$ soil depth; (b) in $45 \mathrm{~cm}$ soil depth; and (c) in $65 \mathrm{~cm}$ soil depth.

\subsection{Water Use Efficiency in Different Saline Soils}

Seed cotton yield was higher in low saline soil than that in higher saline soil. The seed cotton yield was highest $\left(6.64 \mathrm{t} \cdot \mathrm{ha}^{-1}\right)$ in the low saline soil at Korla and lowest $\left(2.39 \mathrm{t} \cdot \mathrm{ha}^{-1}\right)$ in the high saline soil at Aksu (Table 3). The yield measured in this paper was covered within the regime from the reported cotton yield data in different treatments and different locations in Xinjiang $\left(1.8-3.6 \mathrm{t} \cdot \mathrm{ha}^{-1}\right.$ on a saline wasteland [45]; 3.0 to $5.9 \mathrm{t} \cdot \mathrm{ha}^{-1}$ in the southern Xinjiang [43]; 5.5 to $6.5 \mathrm{t} \cdot \mathrm{ha}^{-1}$ at Aksu [46]; 5.3-6.5 $\mathrm{t} \cdot \mathrm{ha}^{-1}$ at Shihezi [47]; $7.0 \mathrm{t} \cdot \mathrm{ha}^{-1}$ in the south of Xinjiang [48]). The Chinese average cotton yield data for $2012 / 13$ was $1.44 \mathrm{~kg} \cdot \mathrm{ha}^{-1}$, which was higher than the world average data $\left(0.77 \mathrm{~kg} \cdot \mathrm{ha}^{-1}\right)$ and is bigger than that in USA $\left(0.99 \mathrm{~kg} \cdot \mathrm{ha}^{-1}\right)$, India $\left(0.49 \mathrm{~kg} \cdot \mathrm{ha}^{-1}\right)$, Pakistan $\left(0.68 \mathrm{~kg} \cdot \mathrm{ha}^{-1}\right)$ and Brazil $\left(1.43 \mathrm{~kg} \cdot \mathrm{ha}^{-1}\right)[49]$. 
Table 3. The field management data and water use efficiency of different saline soils in two experimental stations in Tarim River Basin in 2012.

\begin{tabular}{|c|c|c|c|c|c|c|c|c|c|c|c|}
\hline \multirow{2}{*}{ Location } & Soil Salinity & Sowing & Harvest & Fert N & Fert $P$ & Fert K & \multirow{2}{*}{$\begin{array}{c}\text { Irrigation }^{1} \\
(\mathrm{~mm})\end{array}$} & \multirow{2}{*}{$\begin{array}{c}\text { Precipitation }^{1} \\
(\mathrm{~mm})\end{array}$} & \multirow{2}{*}{$\frac{\text { Yield }^{2}}{\left(\mathbf{t} \cdot \mathbf{h a}^{-1}\right)}$} & IWUE & WUE \\
\hline & Level & Date & Date & & $\left(\mathrm{kg} \cdot \mathrm{ha}^{-1}\right)$ & & & & & \multicolumn{2}{|c|}{$\left(\mathrm{kg}^{\cdot} \mathrm{ha}^{-1} \cdot \mathrm{mm}^{-1}\right)$} \\
\hline Korla & Low & 04.05 & 04.09 & 331 & 124 & 108 & 571 & 128 & 6.64 & $11.6^{\mathrm{a}}$ & $9.5^{\mathrm{a}}$ \\
\hline Aksu & Low & 08.04 & 15.09 & 306 & 294 & 55 & 878 & 49 & 4.48 & $5.1^{b}$ & $4.8^{b}$ \\
\hline Aksu & Middle & 25.04 & 10.09 & 317 & 88 & 135 & 878 & 49 & 4.68 & $5.3^{b}$ & $5.0^{\mathrm{b}}$ \\
\hline
\end{tabular}

Notes: ${ }^{1}$ the amount was within the growing season; ${ }^{2}$ seed cotton yield; Fert, fertilizer; IWUE, irrigation water use efficiency; WUE, water use efficiency; values in column IWUE or WUE followed by the different letters $(a, b, c)$ indicate significant differences among treatments at 0.05 levels.

Precipitation at Korla $(128 \mathrm{~mm})$ was much higher than that at Aksu $(49 \mathrm{~mm})$ during the cotton growing season in 2012. More irrigation water (804-878 mm) was used at Aksu, compared to $571 \mathrm{~mm}$ irrigation water at Korla. A significant difference was determined in water use efficiency for different salinity levels between low saline soil (WUE $10 \mathrm{~kg} \cdot \mathrm{ha}^{-1} \cdot \mathrm{mm}^{-1}$, IWUE $12 \mathrm{~kg} \cdot \mathrm{ha}^{-1} \cdot \mathrm{mm}^{-1}$ ) at Korla, low and middle saline soil $\left(5 \mathrm{~kg} \cdot \mathrm{ha}^{-1} \cdot \mathrm{mm}^{-1}\right)$, and high saline soil $\left(3 \mathrm{~kg} \cdot \mathrm{ha}^{-1} \cdot \mathrm{mm}^{-1}\right)$ at Aksu by the student $t$ test at the 0.05 level. EC had affected water use efficiency mainly through the cotton yield. EC was negatively correlated with cotton yield $(p<0.01)$ at Maigaiti county in Xinjiang [50]. Two years of different salinity and fertilization treatment under cotton showed the IWUE changed from 0.7 to $1.5 \mathrm{~kg} \cdot \mathrm{m}^{-3}$ at Shihezi in Xinjiang [47]. Southern Xinjiang had an average cotton yield over three years from 3.6 to $5.1 \mathrm{t} \cdot \mathrm{ha}^{-1}$, and irrigation water productivity between 0.91 and $1.16 \mathrm{~kg} \cdot \mathrm{m}^{-3}$ with a low EC in the top $30 \mathrm{~cm}$ soil from 3 to $11 \mathrm{dS} \cdot \mathrm{m}^{-1}$ [43]. As research mentioned above, our WUE data were lower $\left(0.53 \mathrm{~kg} \cdot \mathrm{m}^{-3}\right)$, except for WUE and IWUE data at Korla.

\section{Discussion}

\subsection{Soil Water Retention in Relation to Different Soil Properties}

Soil texture, organic matter content, and bulk density all together can influence soil water retention. The order of sand content in $25 \mathrm{~cm}$ soil depth was low salinity soil at Korla $(59.3 \%)>$ high salinity soil at Aksu (38.5\%) > middle salinity soil at Aksu (19.9\%) > low salinity soil at Aksu (9\%) (Table 2). The soil textures have effect on soil water retention through soil physical process by increasing or decreasing of the field capacity. The texture mainly influenced the matric suction power. At $25 \mathrm{~cm}$ depth soil, the low saline soil at Aksu had the lowest sand and highest clay and silt content (Table 2), which had the highest matric suction power compared to the others (Figure 4). Research on the effect of clay content on well-graded sands due to infiltration indicated an increase in matric suction with an increase in the clay content in the mixture of sand and clay [51]. Soil organic carbon increases soil water retention mainly through increasing aggregation, increasing the biological activity and reducing bulk density. The order of soil organic carbon content in $25 \mathrm{~cm}$ soil depth was low salinity $\left(6.8 \mathrm{~g} \cdot \mathrm{kg}^{-1}\right)$ soil at Aksu $>$ low salinity soil at Korla $\left(4.8 \mathrm{~g} \cdot \mathrm{kg}^{-1}\right)>$ middle salinity soil $\left(4.4 \mathrm{~g} \cdot \mathrm{kg}^{-1}\right)$ at Aksu $>$ high salinity soil $\left(2.1 \mathrm{~g} \cdot \mathrm{kg}^{-1}\right)$ at Aksu (Table 2). The high saline soil at Aksu with the lowest SOC content had the highest bulk density and the low saline soil at Aksu with the highest soil organic carbon 
content had the lowest bulk density (Table 2). The soil water retention increased, when the bulk density was reduced [31,52]. At high organic carbon values all soils from the U.S. National Soil Characterization database showed an increase in water retention and the largest increase was in sandy and silt soils [29]. The low saline soil at Aksu had the lowest total suction power, lowest bulk density $\left(1.37 \mathrm{~g} \cdot \mathrm{cm}^{-3}\right)$, sand content $\left(11.8 \%\right.$, more fine-textured soil), highest SOC content $\left(6.8 \mathrm{~g} \cdot \mathrm{kg}^{-1}\right)$ in topsoil, which indicated that the low saline soil at Aksu had better macro-aggregate structure, compared to the high salinity soil, which had the highest total suction power, the highest bulk density $\left(1.70 \mathrm{~g} \cdot \mathrm{cm}^{-3}\right)$, and lowest soil organic carbon content $\left(2.1 \mathrm{~g} \cdot \mathrm{kg}^{-1}\right)$ (Figure 5, Table 2). The water logging problem in deeper soil of higher salinity soil induced low suction power but the higher total suction power because of the higher osmotic potential (Figures 3-5). This hindered a deeper rooting in the saturated subsoil.

\subsection{Soil Water Retention Curves}

The different soil matric potentials play an important role in the salt concentration in the soil. Many experiments have shown a good relationship between plant growth and soil matric potential. Average ECe value in the root zone, after the growing increased and as the control target of soil matric potential decreased had a linear relationship between these factors [53]. A three year experiment on salt distributions and the growth of cotton under different irrigation regimes in Xinjiang in an extremely dry and saline wasteland with drip irrigation showed a favorable low salinity zone existed in the root zone throughout the growing season, when the soil matric threshold was controlled below $-25 \mathrm{kPa}$ [53]. Highest irrigation water use efficiency values were recorded when the soil matric potential was around $-20 \mathrm{kPa}$ [53]. Matric potential plays an important role in salt accumulation in soil. The amount of salt removed from 0 to $80 \mathrm{~cm}$ depth decreased with decreasing soil matric potential [16]. In our research, there is a little different from the earlier studies. Only the low saline soil at Korla and the high saline soil at Aksu kept the soil matric suction below $30 \mathrm{kPa}$ in $65 \mathrm{~cm}$ soil profile during whole cotton growing season (Figure 4) and the yield at Korla showed the highest value $\left(6.64 \mathrm{t} \cdot \mathrm{ha}^{-1}\right.$ ) (Table 3). The water logging in high saline soil at Aksu (Figure 3) induced oxygen deficiency. The low soil matric potential could not offset the high osmotic disadvantages, which suggested that the irrigation volume should not be greatly reduced in high saline soil at Aksu. To reduce the matric suction, the irrigation frequency should be increased in June, July, and August to loose rewetting effects of the low saline soil at Aksu, which induced the higher soil suction power fluctuation (Figure 4). When we consider the higher soil water content in low saline soil (20\%-29\%) than in middle saline soil $(18 \%-24 \%)$ at $40 \mathrm{~cm}$ soil profile at Aksu with the same irrigation and precipitation amount and the value of the yield $\left(4.48 \mathrm{t} \cdot \mathrm{ha}^{-1}\right.$ in low salinity, $4.68 \mathrm{t} \cdot \mathrm{ha}^{-1}$ in middle salinity), the irrigation water was overused in low saline soil at Aksu.

The difference in SWCCs (Soil Water Characteristic Curves) was mainly related to the soil salinity level (Figure 5). Salt stress reduced the growth of plants [15,21,53-56]. The high saline soil had the highest suction power $(5400 \mathrm{kPa})$ (Figure 5). Salinity had a pronounced negative effect on microorganism activity, mainly through the metabolic burden imposed by the need for stress tolerance mechanisms [57]. Salt stress reduces the growth of plants [21,54-56] and also effects the soil microbial 
activity. Research on the different salinity effects on soil microbial activity in soils of varying texture showed cumulative $\mathrm{CO}_{2}$ in soil decreasing significantly with increasing osmotic potential $[58,59]$.

\subsection{Water Use Efficiency in Different Saline Soils}

In Xinjiang province drip irrigated cotton fields, the highest seed cotton yield was obtained, when the matric potential threshold was controlled above $-30 \mathrm{kPa}$ in 2008 and $-0 \mathrm{kPa}$ in 2009 and 2010 and water use value tended to increase as the soil matric potential threshold from $-30 \mathrm{kPa}$ increased to $-20 \mathrm{kPa}$ in 2009 and 2010 under plastic mulched drip irrigation in Xinjiang [12]. The irrigation type [60], irrigation rate [46] and the irrigation amount [10] have effected on the cotton yield. Especially, Soil salinity and sodicity can be maintained at acceptable low levels by appropriate preplant irrigation[61].

The cotton seed yield increased as the soil matric potential control target increased [53]. The low saline soil at Korla kept the soil matric suction below $30 \mathrm{kPa}$, the soil suction below $3500 \mathrm{kPa}$ and had the highest yield $\left(6.64 \mathrm{~kg} \cdot \mathrm{ha}^{-1}\right)$, which prevented high salinity stress in the cotton during the growing season, producing the highest yields and highest water use efficiency $\left(12 \mathrm{~kg} \cdot \mathrm{ha}^{-1} \cdot \mathrm{mm}^{-1}\right)$ (Table 3 , Figures 4 and 5). Although the soil matric suction of high saline soil was below $30 \mathrm{kPa}$ (Figure 4), considering the highest osmotic suction (Figure 5), and the waterlogging problem below $40 \mathrm{~cm}$ soil profile (Figure 3), it did not bring much profit to the yield $\left(2.8 \mathrm{~kg} \cdot \mathrm{ha}^{-1}\right)$ (Table 3). The main reason for decreased root length in cotton under drip irrigation with mulch film was localized accumulation of salinity [62] and the cotton yield increased with the root biomass increase [63]. For the high saline soil one would need a better drainage. This will deepen the root zone, improve the leaching, reduce the salinity and finally increase the yield. Thereby it could save water and increase WUE as well. On the other hand, one need water more irrigation to alleviate the salinity problem. Compared to low saline soils at Aksu, the low saline soil at Korla saved $110 \mathrm{~mm}$ irrigation and $103 \mathrm{~mm}$ total water to reach $1 \mathrm{t} \cdot \mathrm{ha}^{-1}$ yield and increased water use efficiency by $5 \mathrm{~kg} \cdot \mathrm{ha}^{-1} \cdot \mathrm{mm}^{-1}$ and $7 \mathrm{~kg} \cdot \mathrm{ha}^{-1} \cdot \mathrm{mm}^{-1}$ for WUE and IWUE respectively (Table 3 ).

With the relationship of soil water and soil matric suction, the osmotic suction, the soil texture and soil organic carbon content and total nitrogen, there were the models with strong closed relationship $\left(R^{2}=1\right)$ to modelling the soil water content (Figure 6). The soil organic carbon, and soil total nitrogen content, soil texture, which affected the soil matric suction, also affected the soil water content and reduced the salt effect to cotton. The laboratory experiment showed the SOC could restrict the soil water evapotranspiration, salt accumulation and increased the salt leaching [64]. A field experiment showed that farmyard manure could reduce the soil salinity and sodicity and increased cotton yield [65]. In the cotton field in Xinjiang, the soil fertility amelioration is a way to increase the leaching and soil water content, water use efficiency and resist the harm of salinity. 


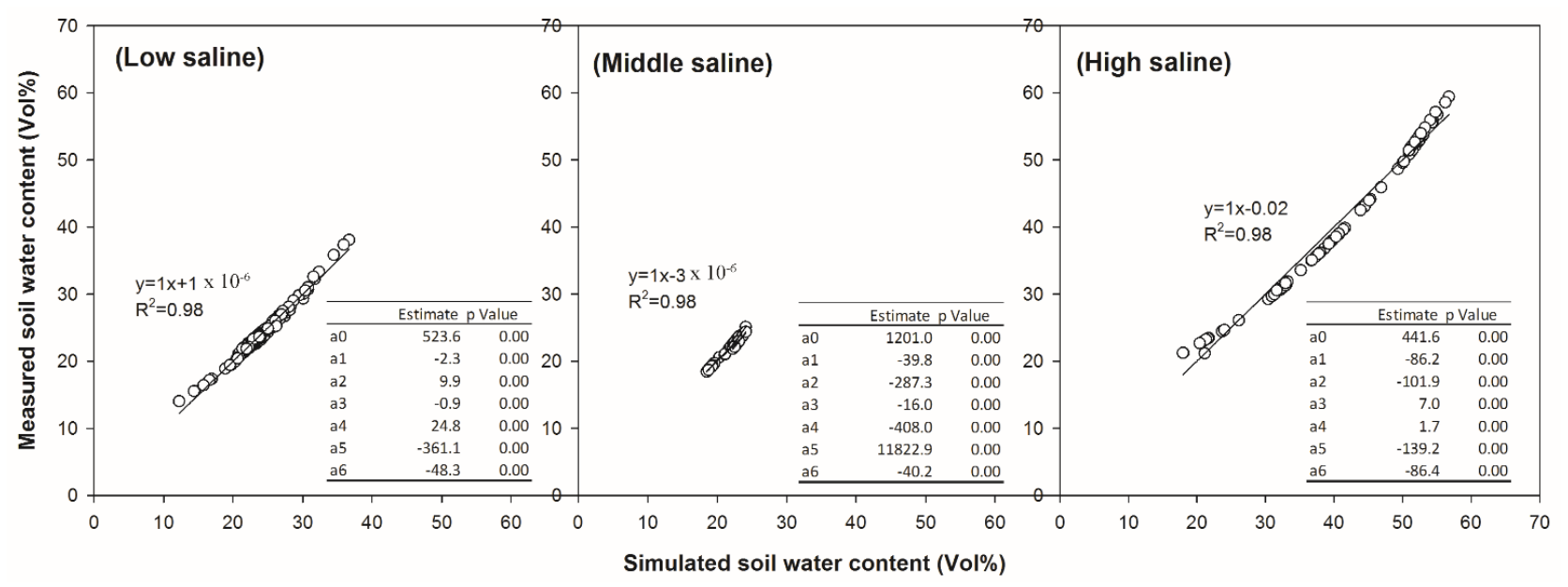

Figure 6. The relationship between the simulated and the measured soil water content with modelling $\left(\mathrm{Vol}_{\%}=\mathrm{a} 0+\mathrm{a} 1 \times \mathrm{pF}_{1}+\mathrm{a} 2 \times\right.$ clay $\left.\%+\mathrm{a} 3 \times \operatorname{silt} \%+\mathrm{a} 4 \times \mathrm{C}_{\text {org }}+\mathrm{a} 5 \times \mathrm{N}_{\text {tot }}+\mathrm{a} 6 \times \mathrm{pF}_{2}\right)$ (pF1: $\mathrm{pF}$ matric, $\mathrm{pF} 2$ : $\mathrm{pF}$ osmetic, $\mathrm{C}_{\text {org }}$ : $(\mathrm{g} / \mathrm{kg}), \mathrm{N}_{\text {tot: }}(\mathrm{g} / \mathrm{kg})$ ) (a) in low saline soil; (b) in middle saline soil; and (c) in high saline soil.

\section{Conclusions}

Based on the experimental data, the relationships between soil water retention, water consumption, water use efficiency and yield were systematically analyzed. The mechanisms of soil moisture and salinity distribution and transport together with the relationship of soil water retention in different saline soils showed that the soil water content (15\%-23\%) at the top $40 \mathrm{~cm}$ soil, lower suction power (below $3500 \mathrm{kPa}$ ) and lower matric suction soil (below $30 \mathrm{kPa}$ ) in low saline soil had the highest water use efficiency and higher yield. The water resource limitation and increasing salinization danger, the physical and chemical properties, matric and osmotic suction, and water logging problem should all be considered for water use efficiency in field management. For example: draining the water logging fields, increasing irrigation frequency, reducing the irrigation amount depending on the soil texture, increasing the manure fertilization. A feasible irrigation with reduction of the salinity harm combined with increasing the soil fertility should be the way to increase water use efficiency in the Tarim River Basin.

\section{Acknowledgments}

The study was funded by the Project SuMaRiO of BMBF (German Federal Ministry of Science and Technology)-Sustainable Management of River Oases along the Tarim River, Institute of Soil Science and Land Evaluation of Hohenheim University, Germany and the National Natural Science Foundation (41201042), Xinjiang Province Youth Science and Technology Innovation Talents Project (2013731029), the Chinese academy of sciences "Western Light" of personnel plan the western doctor special (XBBS201208) and National Scientific and Technological support Program of China (Grant No. 2013BAC10B01). The delivery of data from the research stations Aksu and Korla, especially, the data cooperation with the Pengnian Yang of College of Hydraulic and Civil Engineering of Xinjiang Agricultural University are greatly acknowledged. We are also grateful to Kathleen Regan, Institute of Soil Science and Land Evaluation and Wolfram Spreer, Institute of Agricultural Engineering, Hohenheim University for providing help in revision of this manuscript. 


\section{Author Contributions}

Theresa Schiller and Karl Stahr designed the field experiment. Theresa Schiller performed the experimental work and data collection. Xiaoning Zhao performed statistical analysis and prepared the manuscript. Hussein Othmanli performed the soil data collection and analysis. Chengyi Zhao, Yu Sheng, Shamaila Zia and Joachim Müller gave their support through the field experiments and data exchange.

\section{Conflicts of Interest}

The authors declare no conflict of interest.

\section{References}

1. Hao, X.M.; Chen, Y.N.; Li, W.H. Impact of anthropogenic activities on the hydrologic characters of the mainstream of the Tarim River in Xinjiang during the past 50 years. Environ. Geol. 2009, $57,435-445$.

2. Qi, F.; Wei, L.; Jianhua, S.; Yonghong, S.; Yewu, Z.; Zongqiang, C.; Haiyang, X. Environmental effects of water resource development and use in the tarim river basin of Northwestern China. Environ. Geol. 2005, 48, 202-210.

3. Feng, Q.; Liu, W. Environmental conditions leading to the formation of holocene soil layers in the Northern Taklimakan Desert, Tarim Basin, Northwest China. Geol. J. 2005, 40, 23-34.

4. Feng, Q.; Cheng, G.D.; Masao, M.K. Trends of water resource development and in arid North-West China. Environ. Geol. 2000, 39, 831-838.

5. Chen, X.B.; Yang, J.S.; Liu, C.Q.; Hu, S.J. Soil salinization under integrated agriculture and its countermeasures in Xinjing (in Chinese with English abstract). Soils 2007, 39, 347-353.

6. Hou, Z.A.; Wang, H.Y.; Gong, J.; Xiao, L.; Ma, L.; Qi, T. Salt distribution and accumulation as affected by under-film drip irrigation with saline water in an arid region (in Chinese with English abstract). Chin. J. Soil Sci. 2008, 39, 16-24.

7. Chen, Y.; Ye, Z.; Shen, Y. Desiccation of the tarim river, xinjiang, china, and mitigation strategy. Quatern. Int. 2011, 244, 264-271.

8. Zhang, X.Y.; Cai, H.J. Effects of regulatd deficit irrigation on plastic effect-mulched cotton (in Chinese with English abstract). J. Northwest Sci. Tech. Univ. Agric. For. 2001, 29, 9-12.

9. Wang, C.R.; Tian, X.H.; Li, S.H. Effects of plastic sheet-mulching on ridge for water-harvesting cultivation on wue and yield of winter heat. Sci. Agric. Sin. 2004, 37, 208-214.

10. Hu, X.T.; Chen, H.; Wang, J.; Meng, X.B.; Chen, F.H. Effects of soil water content on cotton root growth and distribution under mulched drip irrigation (in Chinese with English abstract). Agric. Sci. China 2009, 8, 709-716.

11. Hu, S.; Song, Y.; Zhou, H.; Tian, C. Experimental study on water use efficiency of cotton in the tarim river basin. Agric. Res. Arid Areas 2002, 20, 66-70.

12. Kang, Y.; Wang, R.; Wan, S.; Hu, W.; Jiang, S.; Liu, S. Effects of different water levels on cotton growth and water use through drip irrigation in an arid region with saline ground water of Northwest China. Agric. Water Manag. 2012, 109, 117-126. 
13. Zhao, C.Y.; Sheng, Y.; Yimam, Y. Quantifying the impacts of soil water stress on the winter wheat growth in an arid region, Xinjiang. J. Arid Land 2009, 1, 34-42.

14. Zhao, C.Y.; Yan, Y.Y.; Yimamu, Y.; Li, J.Y.; Zhao, Z.M.; Wu, L.S. Effects of soil moisture on cotton root length density and yield under drip irrigation with plastic mulch in aksu oasis farmland. J. Arid Land 2010, 2, 243-249.

15. Dong, H.; Li, W.; Tang, W.; Zhang, D. Early plastic mulching increases stand establishment and lint yield of cotton in saline fields. Field Crop Res. 2009, 111, 269-275.

16. Wang, R.; Kang, Y.; Wan, S.; Hu, W.; Liu, S.; Jiang, S.; Liu, S. Influence of different amounts of irrigation water on salt leaching and cotton growth under drip irrigation in an arid and saline area. Agric. Water Manag. 2012, 110, 109-117.

17. Chen, X.B.; Yang, J.S.; Zhang, F.D.; Hu, S.J.; Li, H. Control of soil water salinity variatons based on crop-salt-water production function in Tarim irrigation area (in Chinese with English abstract). J. Irrig. Drain. 2007, 26, 75-78.

18. Liu, M.X.; Yang, J.S.; Li, X.M.; Yu, M.; Wang, J. Effects of irrigation water quality and drip tape arrangement on soil salinity, soil moisture distribution, and cotton yield (gossypium hirsutum 1.) under mulched drip irrigation in Xinjiang, China. J. Integr. Agric. 2012, 11, 502-511.

19. Ma, D.; Wang, Q.; Lai, J. Field experimental studies on the effects of water quality and drip rate on soil salt distribution in drip irrigation under film. Trans. Chin. Soc. Agric. Eng. 2005, 21, 42-46. (In Chinese)

20. Thomsen, I.K.; Schjønning, P.; Jensen, B.; Kristensen, K.; Christensen, B.T. Turnover of organic matter in differently textured soils. II. Microbial activity as influenced by soil water regimes. Geoderma 1999, 89, 199-218.

21. Chen, M.; Kang, Y.; Wan, S.; Liu, S.P. Drip irrigation with saline water for oleic sunflower (helianthus annuus 1.). Agric. Water Manag. 2009, 96, 1766-1772.

22. Kang, Y.; Wan, S. Effect of soil water potential on radish (raphanus sativus 1.) growth and water use under drip irrigation. Sci. Hortic. 2005, 106, 275-292.

23. Jiao, Y.P.; Kang, Y.H.; Wan, S.Q.; Liu, W. Effect of soil matric potential on waxy corn (zea mays 1. Sinesis kulesh) growth and water use under drip irrigation in saline soils of arid areas. In Proceedings of the 8th International Dryland Development Conference, Beijing, China, 25-28 February 2006.

24. Nimmo, J.R. Modeling structural influences on soil water retention. Soil Sci. Soc. Am. J. 1997, 61, 712-719.

25. Kironchi, G.; Kinyali, S.M.; Mbuvi, J.P. Environmental influence on water characteristics of soils in two semi-arid catchments in Laikipia, Kenia. Afr. Crop Sci. J. 1995, 3, 479-486.

26. Pachepsky, Y.A.; Rawls, W.J. Soil structure and pedotransfer functions. Eur. J. Soil Sci. 2003, 54, 443-451.

27. Juhász, C.E.P.; Cooper, M.; Cursi, P.R.; Ketzer, A.O.; Toma, R.S. Savanna woodland soil micromorphology related to water retention. Sci. Agric. 2007, 64, 344-354.

28. Hollis, J.M.; Jones, R.J.A.; Palmer, R.C. The effects of organic matter and particle size on the water-retention properties of some soils in the west midlands of England. Geoderma 1977, 17, 225-238.

29. Rawls, W.J.; Pachepsky, Y.A.; Ritchie, J.C.; Sobecki, T.M.; Bloodworth, H. Effect of soil organic carbon on soil water retention. Geoderma 2003, 116, 61-76. 
30. Reeve, M.J.; Smith, P.D.; Thomasson, A.J. The effect of density on water retention properties of field soils. J. Soil Sci. 1973, 24, 355-367.

31. Walczak, R.T.; Moreno, F.; Sławiński, C.; Fernandez, E.; Arrue, J.L. Modeling of soil water retention curve using soil solid phase parameters. J. Hydrol. 2006, 329, 527-533.

32. Abrol, I.P.; Khosla, B.K.; Bhumbla, D.R. Relationship of texture to some important soil moisture constants. Geoderma 1968, 2, 33-39.

33. Tutiempo. Global Climate Data. Available online: http://www.tutiempo.net/en/Climate/ (accessed on 1 January 2014).

34. Lu, R.K. Soil Agricultural Chemical Analysis; Beijing Agricultural Technology press: Beijing, China, 1983. (In Chinese)

35. The Ministry of Agriculture of People's Republic of China. The Notification of Cotton Yield Calculation, 2010. Available online: http://www.moa.gov.cn/govpublic/ZZYGLS/201008/ t20100816_1619412.htm (accessed on 1 January 2013). (In Chinese)

36. Campbell, G.S. Soil water potential measurement: An overview. Irrig. Sci. 1988, 9, 265-273.

37. Or, D.; Wraith, J.M. Soil water content and water potential relationships. In Handbook of Soil Science; CRC press: Boca Raton, FL, USA, 2000; pp. A53-A85.

38. Rengasamy, P. Soil salinity and sodicity. In Growing Crops with Reclaimed Wastewater; Inkata press: Melbourne, Australia, 2006; pp. 125-138.

39. Regional Salinity, L. Diagnosis and Improvement of Saline and Alkali Soils; U.S. Department of Agriculture: Washington, DC, USA, 1954.

40. Hu, S.; Shen, Y.; Chen, X.; Gan, Y.; Wang, X. Effects of saline water drip irrigation on soil salinity and cotton growth in an oasis field. Ecohydrology 2013, 6, 1021-1030.

41. Zhang, Y.; Wang, L.H.; Sun, S.M.; Chen, X.L.; Liang, Y.J.; Hu, S.J. Indexes of salt tolerance of cotton in akesu river irrigation destrict (in Chinese with English abstract). Sci. Agric. Sin. 2011, 44, 2051-2059.

42. Yadav, S.; Irfan, M.; Ahmad, A.; Hayat, S. Causes of salinity and plant manifestations to salt stress: A review. J. Environ. Biol. 2011, 32, 667-685.

43. Wang, Z.; Jin, M.; Šimůnek, J.; van Genuchten, M.T. Evaluation of mulched drip irrigation for cotton in arid Northwest China. Irrig. Sci. 2014, 32, 15-27.

44. Zhang, N.; Zhao, Y.S.; Yu, G.R. Simulated annual carbon fluxes of grassland ecosystems in extremely arid conditions. Ecol. Res. 2009, 24, 185-206.

45. Wang, R.; Kang, Y.; Wan, S. Effects of different drip irrigation regimes on saline-sodic soil nutrients and cotton yield in an arid region of Northwest China. Agric. Water Manag. 2015, 153, 1-8.

46. Danierhan, S.; Shalamu, A.; Tumaerbai, H.; Guan, D. Effects of emitter discharge rates on soil salinity distribution and cotton (gossypium hirsutum 1.) yield under drip irrigation with plastic mulch in an arid region of Northwest China. J. Arid Land 2013, 5, 51-59.

47. Min, W.; Guo, H.; Zhou, G.; Zhang, W.; Ma, L.; Ye, J.; Hou, Z. Root distribution and growth of cotton as affected by drip irrigation with saline water. Field Crop Res. 2014, 169, 1-10.

48. Deng, Z.; Bei, D.; Zou, G.L.; Cong, J.; Li, Y.; Cai, J.M.; Feng, J.J. Effects of water and nitrogen regulation on the yield and water and nitrogen use efficiency of cotton in South Xinjiang, Northwest China under plastic mulched drip irrigation. Chin. J. Appl. Ecol. 2013, 24, 2525-2532. 
49. Dai, J.; Dong, H. Intensive cotton farming technologies in China: Achievements, challenges and countermeasures. Field Crop Res. 2014, 155, 99-110.

50. Zheng, Z.; Zhang, F.; Ma, F.; Chai, X.; Zhu, Z.; Shi, J.; Zhang, S. Spatiotemporal changes in soil salinity in a drip-irrigated field. Geoderma 2009, 149, 243-248.

51. Jeong, S.; Kim, J.; Lee, K. Effect of clay content on well-graded sands due to infiltration. Eng. Geol. 2008, 102, 74-81.

52. Horn, R.; Taubner, H.; Wuttke, M.; Baumgartl, T. Soil physical properties related to soil structure. Soil Tillage Res. 1994, 30, 187-216.

53. Wang, R.; Kang, Y.; Wan, S.; Hu, W.; Liu, S.; Liu, S. Salt distribution and the growth of cotton under different drip irrigation regimes in a saline area. Agric. Water Manag. 2011, 100, 58-69.

54. Bassil, E.S.; Kaffka, S.R. Response of safflower (carthamus tinctorius 1.) to saline soils and irrigation i. Consumptive water use. Agric. Water Manag. 2002, 54, 67-80.

55. Bassil, E.S.; Kaffka, S.R. Response of safflower (carthamus tinctorius 1.) to saline soils and irrigation ii. Crop response to salinity. Agric. Water Manag. 2002, 54, 81-92.

56. Kang, Y.; Wang, F.X.; Liu, H.J.; Yuan, B.Z. Potato evapotranspiration and yield under different drip irrigation regimes. Irrig. Sci. 2004, 23, 133-143.

57. Schimel, J.; Balser, T.C.; Wallenstein, M. Microbial stress-response physiology and its implications for ecosystem function. Ecology 2007, 88, 1386-1394.

58. Setia, R.; Marschner, P.; Baldock, J.; Chittleborough, D.; Smith, P.; Smith, J. Salinity effects on carbon mineralization in soils of varying texture. Soil Biol. Biochem. 2011, 43, 1908-1916.

59. Chowdhury, N.; Nakatani, A.S.; Setia, R.; Marschner, P. Microbial activity and community composition in saline and non-saline soils exposed to multiple drying and rewetting events. Plant Soil 2011, 348, 103-113.

60. Tang, L.-S.; Li, Y.; Zhang, J. Biomass allocation and yield formation of cotton under partial rootzone irrigation in arid zone. Plant Soil 2010, 337, 413-423.

61. Nightingale, H.I.; Davis, K.R.; Phene, C.J. Trickle irrigation of cotton: Effect on soil chemical properties. Agric. Water Manag. 1986, 11, 159-168.

62. Mai, W.X.; Tian, C.Y.; Li, C.J. Soil salinity dynamics under drip irrigation and mulch film and their effects on cotton root length. Commun. Soil Sci. Plan 2013, 44, 1489-1502.

63. Luo, H.H.; Tao, X.P.; Hu, Y.Y.; Zhang, Y.L.; Zhang, W.F. Response of cotton root growth and yield to root restriction under various water and nitrogen regimes. J. Plant Nutr. Soil Sci. 2015, doi:10.1002/jpln.201400264.

64. Shan, X.Z.; Wei, Y.Q.; Yang, H.J.; Liu, J.F.; Zhang, R. The modelling research on the effect of soil organic carbon content on the soil water and salt movement (in Chinese with English abstract). Soil and Fertilizer. 1996, 5, 1-5.

65. Kahlown, M.A.; Azam, M. Effect of saline drainage effluent on soil health and crop yield. Agric. Water Manag. 2003, 62, 127-138.

(C) 2015 by the authors; licensee MDPI, Basel, Switzerland. This article is an open access article distributed under the terms and conditions of the Creative Commons Attribution license (http://creativecommons.org/licenses/by/4.0/). 